DOI: https://doi.org/10.31933/jemsi.v2i3

Received: 30 November2020, Revised: 15 Desember2020, Publish: 8 Februari 2021

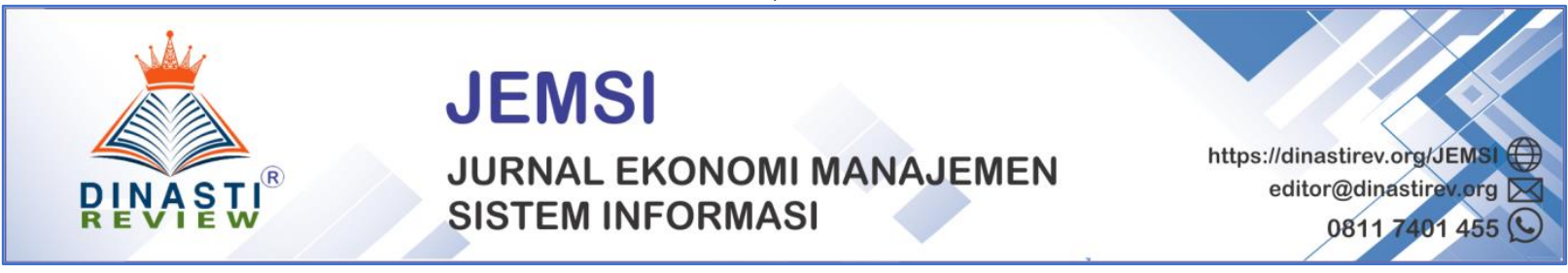

\title{
ANALISIS KOMPARATIF LAPORAN KEUANGANPT TEMPO SCAN PACIFIC TBK. (TSPC) DENGAN INDUSTRI FOOD AND BEVERAGES YANG TERDAFTAR DI BURSA EFEK INDONESIA PERIODE 2014-2019
}

\section{Rachella Kezia}

Program Studi Magister Manajemen Universitas Mercu Buana, Jakarta, chellakezia@ gmail.com

Corresponding Author: Rachella Kezia

\begin{abstract}
Abstrak: Seiring berkembangnya waktu dan teknologi, persaingan dalam dunia bisnis semakin kompetitif, terutama dengan masuknya sistem perdagangan bebas di suatu negara. Indonesia adalah salah satu negara yang memungkinkan perdagangan bebas. Indonesia dan negara-negara lain ASEAN telah sepakat untuk membuat kesepakatan tentang perdagangan bebas bernama Masyarakat Ekonomi ASEAN (MEA). Makalah ini dibuat dengan tujuan, yaitu menganalisis kinerja keuangan PT Tempo Scan Pacific Tbk. (TSPC) dimana dibandingkan dengan total industri berdasarkan Analisis Rasio Keuangan. Data yang digunakan adalah merupakan laporan keuangan periode 2014-2019 yang terdaftar di Bursa Efek Indonesia (BEI). PT Tempo Scan Pacific Tbk, yakni TSPC telah memulai usaha perdagangan produk famasi sejak tahun 1953. Adapun metode analisis data yang dilakukan di dalam penelitian ini adalah analisis statistik deskriptif dan analisis rasio keuangan. Hasil penelitian ini diharapkan dapat menjadi tolak ukur dalam menilai kinerja keuangan PT Tempo Scan Pacific Tbk. (TSPC).
\end{abstract}

Kata kunci : Rasio Keuangan, Analisis Rasio Keuangan

\section{PENDAHULUAN}

Di era globalisasi ini, Indonesia adalah salah satu negara yang dapat terjadinya perdagangan bebas. Indonesia dengan negara ASEAN telah sepakat untuk membuat kesepakatan tentang perdagangan bebas bernama Masyarakat Ekonomi ASEAN (MEA). Masyarakat Ekonomi ASEAN adalah integrasi ekonomi ASEAN dalam menghadapi perdagangan bebas antara negara-negara ASEAN. Dimana kerjasama ASEAN ini mengarah pada pembentukan komunitas ekonomi ASEAN sebagai integrasi ekonomi dari wilayah ASEAN yang stabil, makmur dan sangat kompetitif. Yang bertujuan mempercepat pertumbuhan ekonomi, kemajuan sosial dan pengembangan budaya. Adanya MEA di Indonesia membuat dunia bisnis terus berupaya mengeluarkan kemampuan, inovasi, dan kemajuan terbaru sehingga usahanya dapat bertahan bahkan berkembang di tengah-tengah sirkulasi produk impor di negara ini. Persaingan yang semakin kompetitif membuat perusahaan memaksimalkan dan mengoptimalkan sumber 
daya yang ada sehingga tetap mencapai tujuan organisasi. Kondisi keuangan dan hasil kinerja perusahaan dapat tercermin dalam laporan keuangan suatu perusahaan, yang pada dasarnya merupakan hasil dari kegiatan akuntansi perusahaan.

Secara umum, tujuan pembentukan perusahaan adalah dengan mengambil keuntungan secara optimal. Perusahaan yang dapat menunjukkan keunggulan kompetitif akan medapatkan keuntungan maksimal, dan dapat menangkap pangsa pasar yang tinggi dimana memiliki dampak yang baik pada perusahaan itu sendiri, terutama dalam hal keuangan perusahaan. Manfaat yang diperoleh akan berdampak positif pada kinerja keuangan suatu perusahaan. Kinerja keuangan menunjukkan kondisi keuangan perusahaan yang diukur dengan alat analitis tertentu.

Salah satu cara untuk melihat kesehatan keuangan suatu perusahaan adalah mengamati laporan keuangannya. Secara umum, investor akan menganalisis laporan keuangan perusahaan sebagai inisasi pengambilan keputusan membuat keputusan untuk berinvestasi, dengan harapan bahwa mereka akan mendapatkan kepemilikan maksimum dengan risiko minimal. Karena investor harus menganalisis laporan keuangan perusahaan, sehingga nantinya akan memengaruhi pengambilan keputusan tentang langkah-langkah investasi yang sesuai di masa depan pada perusahaan teresebut. Ukuran yang sering digunakan untuk menganalisis kinerja keuangan suatu perusahaan adalah laporan keuangan. Dengan menggunakan analisis laporan keuangan, investor dapat menemukan pengembangan perusahaan saat ini dan masa depan sehingga dapat diketahui sehat atau tidaknya kinerja keuangan suatu perusahaan.

Menurut Harahap (2013) laporan keuangan menggambarkan kondisi keuangan dan hasil usaha suatu perusahaan pada saat tertentu atau jangka waktu tertentu. Laporan keuangan merupakan kegiatan membandingkan angka-angka yang ada dalam laporan keuangan dengan cara membagi satu angka dengan angka lainnya. Perbandingan dapat dilakukan antara satu komponen dengan komponen dalam satu laporan keuangan atau antar komponen yang ada di antara laporan keuangan. Rasio finansial atau rasio keuangan terdiri dari beberapa macam rasio yang memiliki tujuan yang berbeda-beda, adapun empat di antaranya adalah Rasio Likuiditas, Rasio Solvabilitas, Rasio Turnover Aset, dan Rasio Profitabilitas.

PT Tempo Scan Pacific Tbk. (TSPC) adalah salah satu perusahaan yang merupakan anggota kelompok TEMPO yang mengawasi divisi farmasi. Unit bisnis anak perusahaan terdiri dari pembuatan dan distribusi produk farmasi, kesehatan, kosmetik dan layanan distribusi. Pacific Scan Tempo juga dikembangkan melalui divisi yang terdiri dari Divisi Farmasi, Divisi Perawatan Pribadi, Divisi Kosmetik dan Dibantu dengan Divisi Pemasaran. PT Tempo Scan Pacific Tbk. (TSPC) telah memulai usaha perdagangan produk farmasi sejak tahun 1953. Perusahaan ini telah menghasilkan beberapa produk yang terkenal di pasaran, seperti Bodrex, Hemaviton, Vidoran, NEO rheumacyl, My Baby dan beberapa produk lainnya. Perusahaan ini memiliki 2 fasilitas pabrik yang cukup luas dan yang berlokasi di Cawang dan Cikarang.

Dalam perkembangannya, PT. Tempo Scan Pacific Tbk terus mengembangkan produk yang berfokus pada obat bebas atau over the counter (OTC) yang merupakan andalan perusahaan. Dalam divisi farmasi yang disebut kesehatan konsumen pharma, perusahaan dapat berkontribusi sekitar Rp 1,76 triliun, setara dengan 30,4\% dari total penjualan bersih perusahaan pada tahun 2011. Untuk meningkatkan peningkatan laba perusahaan, Pacific Scan Tempo berencana untuk berkembang produk suplemen yang merupakan kategori baru yang belum diperlihatkan oleh pesaing. Munculnya wacana pengembangan suplemen ini datang dari gaya 
hidup yang dilakukan oleh masyarakat sekarang cenderung lebih padat atau sibuk. Sehingga suplemen menjadi jawaban untuk mengatasi masalah yang ada dalam masyarakat. Dengan perusahaan ini menargetkan penjualan obat OTC sebesar 90\% dan sisa obat etis (obat berdasarkan resep). Produk Pacific Scan telah menyebar lebih dari 45,1\% dari total pasar farmasi nasional. Dengan kata lain, produk-produk perusahaan telah menguasai mayoritas pasar obat nasional. Tidak hanya itu, produk yang dibuat oleh perusahaan juga telah mampu menembus pasar internasional dengan mengimpor ke Malaysia, Filipina, Timur Tengah, Nigeria dan negaranegara lain.

Berikut adalah Laporan Laba-Rugi yang diperoleh oleh PT Tempo Scan Pacific Tbk. (TSPC) selama enam tahun terakhir yang dapat dilihat pada tabel 1.

Tabel 1. Laporan Laba - Rugi (dalam Miliar Rupiah)

\begin{tabular}{|c|c|c|c|c|c|c|}
\hline KETERANGAN & 2014 & 2015 & 2016 & 2017 & 2018 & 2019 \\
\hline Penjualan & 7,512 & 8,181 & 9,138 & 9,565 & 10,088 & 10,994 \\
\hline $\mathrm{Hpp}$ & 4,572 & 5,064 & 5,654 & 5,907 & 6,246 & 6,752 \\
\hline Ebit & 738 & 707 & 719 & 744 & 728 & 796 \\
\hline Biaya Bunga (-) & 10 & 6 & 8 & 24 & 29 & 48 \\
\hline Ebt & 674 & 692 & 692 & 634 & 702 & 797 \\
\hline Pph & 152 & 178 & 173 & 187 & 187 & 201 \\
\hline Laba Th Berjalan & 586 & 529 & 545 & 557 & 540 & 595 \\
\hline Hpp & 4,572 & 5,064 & 5,654 & 5,907 & 6,246 & 6,752 \\
\hline Ebit & 738 & 707 & 719 & 744 & 728 & 796 \\
\hline Biaya Bunga (-) & 10 & 6 & 8 & 24 & 29 & 48 \\
\hline $\mathrm{Ebt}$ & 674 & 692 & 692 & 634 & 702 & 797 \\
\hline Pph & 152 & 178 & 173 & 187 & 187 & 201 \\
\hline Laba Th Berjalan & 586 & 529 & 545 & 557 & 540 & 595 \\
\hline
\end{tabular}

Sumber: Laporan Keuangan Tahunan PT Tempo Scan Pacific Tbk. (TSPC)

\section{TINJAUAN LITERATUR}

Pengertian laporan keuangan menurut Sutrisno adalah hasil akhir dari proses akuntansi yang meliputi dua laporan utama yakni neraca dan laporan laba-rugi. Laporan keuangan disusun dengan tujuan untuk menyediakan informasi keuangan suatu perusahaan kepada pihak-pihak yang berkepentingan sebagai bahan pertimbangan di dalam mengambil keputusan dan sifatnya sebagai pelengkap seperti laporan laba yang ditahan serta laporan sumber dan penggunaan dana atau laporan perubahan posisi keuangan. "Laporan keuangan adalah hasil akhir dari suatu proses pencatatan, pengelolaan dan pemerikasaan dari transaksi finansial dalam suatu badan usaha yang dirancang untuk membuat keputusan baik dalam maupun luar perusahaan mengenai posis keuangan dan hasil usaha perusahaan”. Priyati (2013). Neraca menunjukkan / menggambarkan jumlah aset, liabilitas, dan ekuitas dari perusahaan pada tanggal tertentu. Sementara perhitungan (laporan) laba-rugi menunjukkan hasil yang telah dicapai oleh perusahaan dan beban yang terjadi selama periode tertentu, dan laporan perubahan ekuitas menunjukkan sumber dan penggunaan atau alasan yang menyebabkan perubahan dalam ekuitas perusahaan.

Laporan keuangan bertujuan memberikan informasi mengenai posisi keuangan, kinerja keuangan, dan arus kas entitas yang bermanfaat bagi sebagian besar pengguna laporan keuangan dalam membuat keputusan ekonomi. Laporan keuangan juga merupakan manifestasi dari 
tanggung jawab manajemen untuk penggunaan sumber daya yang dipercayakan kepada mereka dalam mengelola suatu entitas (Hans, 2016). Laporan keuangan lengkap mencakup neraca, laporan laba rugi, laporan perubahan posisi keuangan, catatan dan laporan lain serta materi penjelasan yang merupakan bagian yang tidak terpisahkan dari laporan keuangan ini.

Adapun tujuan daripada laporan keuangan menurut Kasmir (2016), yaitu sebagai berikut :

1. Memberikan informasi terpecaya mengenai jenis dan jumlah asset / properti yang dimiliki perusahaan.

2. Memberikan informasi yang diperlukan mengenai jenis dan jumlah kewajiban serta modal perusahaan.

3. Menyediakan informasi tentang jenis dan jumlah pendapatan yang diperoleh dalam periode tertentu.

4. Memberikan informasi akurat mengenai jumlah pembayaran dan jenis biaya yang dikeluarkan oleh perusahaan dalam periode tertentu.

5. Memberikan informasi mengenai perubaha pada aset, kewajiban, dan modal suatu perusahaan .

6. Memberikan informasi tentang kinerja manajemen perusahaan pada suatu waktu.

7. Memberikan informasi tentang catatan pada laporan keuangan.

\section{Pengertian Analisis Rasio Keuangan}

Menurut Irawati (2005), rasio keuangan adalah teknik analisis dalam bidang manajemen keuangan yang dimanfaatkan sebagai alat ukur kondisi keuangan suatu perusahaan dalam periode tertentu ataupun hasil-hasil usaha dari suatau perusahaan pada satu periode tertentu dengan jalan membandingkan dua buah variabel yang diambil dari laporan keuangan perusahaan, baik daftar neraca maupun laba rugi.

Menurut Irham Fahmi (2012), rasio keuangan atau financial ratioini sangat penting gunanya untuk melakukan analisa terhadap kondisi keuangan perusahaan.Bagi investor jangka pendek dan menengah pada umumnya lebih banyak tertarik kepada kondisi keuangan jangka pendek dan kemampuan perusahaan untuk membayar dividen yang memadai. Informasi tersebut dapat diketahui dengan cara lebih sederhana yaitu dengan menghitung rasio-rasio keuangan yang sesuai dengan keinginan.

Dari pemahaman di atas dapat disimpulkan bahwa rasio keuangan adalah perhitungan matematika yang dilakukan dengan membandingkan pos atau komponen tertentu dalam laporan keuangan yang memiliki hubungan untuk yang nanti ditujukan untuk menunjukkan perubahan dalam kondisi keuangan suatu perusahaan.

Selain tujuan laporan keuangan, laporan keuangan juga memiliki beberapa manfaat. Di mana menurut Agus dan Martono (2010) laporan keuangan yang baik dan akurat dapat memberikan manfaat antara lain dalam : (1) Pengambilan keputusan investasi; (2) Keputusan pemberian kredit; (3) Penilaian aliran kas; (4) Penilaian sumber ekonomi; (5) Melakukan klaim terhadap sumber dana; (6) Menganalisis perubahan yang terjadi terhadap sumber dana; (7) Menganalisis penggunaan dana.

\section{Keunggulan Analisis Rasio Keuangan}


Keunggulan rasio keuangan menurut Irham Fahmi (2012) adalah sebagai berikut : (1) Rasio merupakan angka-angka atau ikhtisar statistikyang lebih mudah dibaca dan ditafsirkan; (2) Merupakan pengganti yang lebih sederhana dari informasi yang disajikan laporan keuangan yang sangat rinci dan rumit; (3) Merupakan pengganti yang lebih sederhana dari informasi yang disajikan laporan keuangan yang sangat rinci dan rumit; (4) Mengetahui posisi perusahaan di tengah industri lain; (5) Sangat bermanfaat untuk bahan dalam mengisi model-model pengambilan keputusan dan model prediksi (Z-score); (6) Menstandardisasi size perusahaan; (7) Lebih mudah memperbandingkan perusahaan dengan perusahaan lain atau melihat perkembangan perusahaan secara periodic atau time series; (8) Lebih mudah melihat tren perusahaan serta melakukan prediksi di masa yag akan datang.

\section{Keterbatasan Analisis Rasio Keuangan}

Selain keunggulan analisis rasio di atas, teknik ini juga memiliki beberapa keterbatasan yang harus diwujudkan ketika digunakan sehingga tidak ada kesalahan dalam penggunaannya. Dalam praktiknya, walaupun rasio keuangan yang digunakan memiliki fungsi dan kegunaan yang cukup banyak bagi perusahaan dalam mengambil keputusan, bukan berarti rasio keuangan yang dibuat sudah menjamin kondisi dan posisi keuangan yang sesungguhnya. Artinya kondisi sesungguhnya belum tentu terjadi seperti hasil perhitungan yang dibuat. Belum dapat dipastikan menjamin kondisi dan posisi keuangan yang sebenarnya. Hal itu dikarenakan rasio-rasio keuangan yang digunakan memiliki banyak kelemahan.

Ada beberapa keterbatasan analisis rasio keuangan menurut Irham Fahmi (2012) yaitu sebagai berikut : (1) Penggunaan rasio keuanganakan memberikan pengukuran yang relatif terhadap kondisi suatu perusahaan; (2) Analisis rasio keuangan hanya dapat dijadikan sebagai peringatan awal dan bukan kesimpulan akhir; (3) Setiap data yang diperoleh yang dipergunakan dalam menganalisis adalah bersumber dari laporan keuangan perusahaan; (4) Pengukuran rasio keuangan banyak yang bersifat artificial.

\section{Jenis-Jenis Rasio Keuangan}

Menurut Agus dan Martono (2010), terdapat enam rasio keuangan yang digunakan dalam menganalisis laporan keuangan perusahaan, yaitu:

1. Rasio Likuiditas (Liquidity Ratio). Rasio yang menunjukkan hubungan antara kas perusahaan dan aktiva lancar lainnya dengan hutang lancar. Rasio ini digunakan untuk mengukur kemampuan perusahaan dalam memenuhi kewajiban finansialnya yang harus segera dipenuhi atau kewajiban jangka pendek. Rasio likuiditas dapat diukur dengan dua rasio yaitu: (1) Current Ratio dan (2) Quick Ratio

2. Rasio Aktivitas (Activity Ratio). Rasio aktivitas dikenal juga sebagai rasio efisiensi, yaitu rasio yang mengukur efisiesi perusahaan dalam menggunakan aset-asetnya. Rasio aktivitas dapat diukur dengan tiga rasio yaitu: (1) Receivable Turnover; (2) Inventory Turnover; dan (3) Total Asset Turnover.

3. Rasio Leverege (Leverage Ratio). Rasio yang mengukur seberapa banyak perusahaan menggunakan dana dari hutang (pinjaman).

4. Rasio Profitabilitas (Profitabillity Ratio). Rasio yang menunjukkan kemampuan perusahaan untuk memperoleh keuntungan dari penggunaan modalnya. Rasio profitabilitas dapat diukur dengan tiga rasio yaitu; (1) Net Profit Margin; (2) ROA; (3) ROE. 
5. Rasio Penilaian (Investment Ratio). Ratio yang memberikan ukuran kemampuan manajemen menciptakan nilai pasar usahanya diatas biaya investasi.

\section{Rasio Likuiditas}

Sebuah perusahaan yang ingin menjaga kesinambungan kegiatan bisnisnya tentu harus memiliki kemampuan untuk melunasi kewajiban keuangan yang segera dilunasi. Di mana dalam menjalankan usahanya perusahaan harus dalam keadaan likuid. Untuk mengetahui perusahaan tersebut likuid atau tidak dapat dilakukan dengan menganalisis rasio likuiditas. Berikut beberapa pendapat mengenai rasio likuiditas menurut para ahli. Menurut Agus dan Martono (2010) bahwa rasio likuiditas "Merupakan indikator kemampuan perusahaan untuk membayar atau melunasi kewajiban-kewajiban finansialnya pada saat jatuh tempo dengan mempergunakan aktiva lancar yang tersedia".

Menurut Brigham dan Houston (2010) adalah "Rasio yang menunjukkan hubungan antara kas dan aset lancar perusahaan lainnya dengan kewajiban lancarnya". Selanjutnya rasio likuiditas menurut Fahmi (2011) menyatakan bahwa : "Rasio likuiditas adalah kemampan suatu perusahaan memenuhi kewajiban jangka pendeknya secara tepat waktu". Berdasarkan pengertian di atas maka dapat disimpulkan bahwa rasio likuiditas digunakan untuk mengukur kemampuan perusahaan dalam membayar semua kewajiban-kewajiban finansial dalam jangka pendeknya atau kewajiban-kewajiban lancarnya pada saat jatuh tempo.

Adapun jenis-jenis rasio likuiditas yang dapat digunakan perusahaan untuk mengukur kemampuan, yaitu sebagai berikut :

1. Rasio Lancar (Current Ratio)

Current Ratio atau ratio lancar adalah ukuran yang umum digunakan atas solvensi jangka pendek, kemampuan suatu perusahaan memenuhi kebutuhan hutang ketika jatuh tempo. Rasio lancar terdiri dari perhitungan rasio likuiditas yang cara perhitungannya paling sederhana dengan perhitungan lainnya. Perhitungan rasio lancar bertujuan mengetahui tingkat kemampuan perusahaan dalam memenuhi kewajiban lancarnya dengan aktiva lancar, yang dimana jenis aktiva ini dapat ditukar dengan kas dalam periode satu tahun. Rumus Current Ratio yang digunakan sebagai berikut :

Current Ratio $=$ Hutang Lancar : Aktiva Lancar x 100\%

2. Rasio Cepat (Quick Ratio)

Quick Ratio atau rasio sangat lancar atau acid test ratio merupakan rasio yang menunjukkan kemampuan perusahaan dalam memenuhi atau membayar kewajiban atau uatang lancar (utang jangka pendek) dengan aktivitas lancar tanpa memperhitungkan nilai sediaan (inventory), dengan kesimpulan merupakan alat yang digunakan untuk mengukur seberapa besar uang kas yang tersedia untuk membayar hutang. Rata-rata standar industry untuk quick ratio adalah 1,5 kali atau $150 \%$. Rumus quick ratio yang digunakan sebagai berikut :

Quick Ratio $=$ Aktiva Lancar-Persediaan : Hutang Lancar x 100\%

3. Rasio Kas (Cash Ratio) 
Cash Ratio atau rasio kas merupakan alat yang digunakan untuk mengukur seberapa besar uang kas yang tersedia untuk membayar utang. Rumus cash ratio yang digunakan sebagai berikut :

Cash Ratio $=$ Kas+Bank : Hutang Lancar

\section{Rasio Perputaran Kas (Cash Turn Over)}

Cash Turn Over atau rasio perputaran berfungsi untuk mengukur tingkat kecukupan modal kerja perusahan yang dibutuhkan untuk membayar tagihan dan membiayai penjualan. Artinya rasio ini digunakan untuk mengukur tingkat ketersediaan kas untuk membayar tagihan (utang) dan biaya-biaya yang berkaitan dengan penjualan. Rumus Cash Turn Over yang digunakan sebagai berikut :

Cash Turn Over $=$ Penjualan Bersih - Modal Kerja Bersih

\section{Rasio Solvabilitas (Leverage)}

Rasio solvabilitas atau leverage ratio merupakan rasio yang digunakan untuk mengukur sejauh mana aset perusahaan dibiayai oleh hutang atau rasio yang digunakan untuk mengukur kemampuan perusahaan untuk membayar semua kewajibannya, baik jangka pendek dan panjang jika perusahaan dilikuidasi. Rasio solvabilitas menggambarkan kemampuan perusahaan melunasi semua utang-utangnya pada saat jatuh tempo. Pengertian solvabilitas menurut Sutrisno (2009) ialah kemampuan suatu perusahaan dalam memenuhi seluruh kewajibannya jika perusahaan dilikuidasi.

Adapun jenis-jenis rasio yang ada dalam rasio solvabilitas yang umum digunakan menurut Kasmir (2016) adalah sebagai berikut:

1. Rasio Hutang (Debt Ratio)

Debt ratio merupakan rasio utang yang digunakan untuk mengukur seberapa besar aktiva perusahaan dibiayai oleh utang atau seberapa besar utang perusahaan berpengaruh terhadap pengelolaan aktiva. Rumus debt ratio yang digunakan adalah sebagai berikut : Debt Ratio $=$ Total Hutang : Total Aktiva x 100\%

2. Rasio Hutang Terhadap Ekuitas (Debt to Equity Ratio)

Debt to equity ratio merupakan rasio yang digunakan untuk menilai utang dengan ekuitas. Rasio ini dicari dengan cara membandingkan antara seluruh utang, termasuk utang lancar dengan seluruh ekuitas. Rasio ini berguna untuk mengetahui jumlah dana yang disediakan peminjam (kreditur) dengan pemilik perusahaan. Dengan kata lain rasio ini digunakan untuk mengetahui setiap rupiah modal sendiri yang dijadikan untuk jaminan utang. Rata-rata standar industry untuk debt to equity ratio adalah $80 \%$. Rumus rasio hutang terhad ap ekuitas yang digunakan adalah sebagai berikut :

Debt to Equity Ratio = Total Hutang : Ekuitas x 100\%

3. Equity Multiplayer

Adalah rasio yang dapat menunjukkan kemampuan perusahaan dalam memanfaatkan ekuitas atau modal yang dimilikinya secara optimal. Rasio ini juga dapat menunjukkan seberapa besar aktiva yang dimiliki perusahaan dibiayai oleh ekuitas atau modal nya. Semakin kecil rasio ini semakin baik bagi perusahaan, karena semakin kecil rasio ini maka semakin besar jumlah modal yang dimiliki perusahaan untuk membiayai aktiva bagi perusahaan. Rumus Equity Multiplayer yang digunakan adalah sebagai berikut : Equity Multiplayer $=$ Total Aktiva $:$ Total Ekuitas 


\section{Capital Structure}

Adalah rasio yang dapat menunjukkan seberapa besar ekuitas atau modal yang dimiliki perusahaan dibiayai atau berasal dari hutang jangka panjang. Semakin besar nilai rasio ini artinya ekuitas atau modal yang dimiliki oleh perusahaan sebagian besar berasal dari pinjaman atau hutang jangka panjang. Apabila perusahaan terlalu banyak memiliki hutang jangka panjang maka akan semakin besar pula beban bunga yang ditanggung oleh perusahaan, karena hutang jangka panjang memiliki presentase bunga yang cukup tinggi. Oleh karena itu, semakin kecil nilai dari rasio ini maka akan semakin baik bagi suatu perusahaan. Rumus capital structure yang digunakan adalah sebagai berikut :

Capital Structure = Perbandingan Utang Jangka panjang dengan Ekuitas

\section{Rasio Aktivitas}

Menurut Hery (2015), rasio aktivitas merupakan rasio yang digunakan untuk mengukur tingkat efisiensi atas pemaanfaat sumber daya yang dimiliki perusahaan, atau untuk menilai kemampuan perusahaan dalam menjalankan aktivitasnya sehari-hari. Rasio ini dikenal juga sebagai rasio pemanfaatan asset, yaitu rasio yang digunakan untuk menilai efektivitas dan intensitas asset perusahaan dalam menghasilkan penjualan. (Kasmir, 2012). Rasio aktivitas dapat mengukur tingkat efisiensi pemanfaatan sumber daya perusahaan (penjualan, sediaan, penagihan piutang, dan lainnya) atau rasio untuk menilai kemampuan perusahaan dalam melaksanakan aktivitas sehari-hari. Adapun jenis-jenis rasio yang ada dalam rasio aktivitas antara lain :

1. Perputaran Piutang (Receivable Turnover)

Rasio Receivable Turnover dapat menunjukkan berapa kali piutang dapat berputar dalam setahun. Semakin tinggi nilai Receivable Turnover atau perputaran piutang pada perusahaan, artinya piutang yang dapat ditagih oleh perusahaan juga semakin banyak sehingga akan memperkecil kemungkinan adanya piutang yang tidak tertagih serta akan memperlancar arus kas. Oleh karena itu semakin tinggi nilai Receivable Turnover atau perputaran piutang pada perusahaan akan semakin baik. Rumus Receivable Turnover yang digunakan adalah sebagai berikut :

Receivable Turnover $=$ Penjualan : Piutang

2. Day's Sales in Receivable

Day's Sales in Receivable adalah rasio untuk mengukur jangka waktu rata-rata yang harus ditunggu perusahaan setelah melakukan penjualan sebelum menerima kas yang merupakan periode penagihan rata-rata. Day's Sales in Receivable dapat menunjukkan berapa lama rata-rata waktu yang dibutuhkan perusahaan untuk menagih setiap piutang yang ada, atau dapat juga dikatakan bahwa rasio ini dapat menunjukkan berapa lama ratarata waktu yang dibutuhkan dalam pelunasan piutang perusahaan. Semakin kecil nilai Day's Sales in Receivable ini, artinya semakin cepat piutang dilunasi atau semakin cepat perusahaan mampu menagih piutang perusahaan sehingga akan memperkecil kemungkinan piutang tidak tertagih serta akan memperlancar arus kas. Oleh karena itu semakin kecil nilai Day's Sales in Receivable pada perusahaan maka akan semakin baik. Rumus Day's Sales in Receivable yang digunakan adalah sebagai berikut :

Day's Sales in Receivable $=365$ hari (asumsi 1 tahun) : Receivable Turnover

3. Perputaran Persediaan (Inventory Turnover) 
Inventory Turnover adalah rasio yang dapat menghitung perputaran persediaan serta mengukur efisiensi pengelolaan persediaan barang dagang perusahaan. Inventory Turnover dapat menunjukkan berapa kali persediaan dapat berputar dalam satu tahun, atau dapat juga dikatakan bahwa rasio ini dapat menunjukkan tingkat efisiensi dari persediaan. Semakin tinggi nilai Inventory Turnover artinya perusahaan dapat menjual persediaan secara maksimal sehingga tidak terjadi penumpukan persediaan di gudang, selain itu tingginya nilai Inventory Turnover juga menunjukkan semakin tingginya perputaran persediaan sehingga dana yang tertanam pada persediaan dapat berputar kembali menjadi uang kas perusahaan. Oleh karena itu, semakin tinggi nilai Inventory Turnover pada perusahaan maka semakin baik.

Rumus Inventory Turnover yang digunakan adalah sebagai berikut : Inventory Turnover $=$ HPP : Persediaan

\section{Perputaran Modal Kerja (Day's Sales Turnover)}

Day's Sales Turnover adalah rasio yang dapat menunjukkan berapa lama rata-rata waktu yang dibutuhkan perusahaan untuk menyimpan persediaan mereka sebelum dijual, atau dapat juga dikatakan bahwa rasio ini dapat menunjukkan berapa lama rata-rata waktu yang dibutuhkan untuk menjual persediaan yang ada di perusahaan. Rumus Day's Sales Turnover yang digunakan adalah sebagai berikut :

Day's Sales Turnover $=365$ hari (asumsi 1 tahun) : Inventory Turnover

\section{Total Asset Turnover}

Total Asset Turnover adalah rasio yang dapat menunjukkan kemampuan perusahaan dalam mengelola seluruh aset yang dimilikinya untuk menghasilkan penjualan. Semakin tinggi nilai Total Asset Turnover artinya semakin tinggi pula penjualan yang dilakukan oleh perusahaan dari hasil mengelola aset yang dimilikinya. Oleh karena itu, semakin tinggi nilai Total Asset Turnover pada perusahaan maka semakin baik. Rumus Total Asset Turnover yang digunakan adalah sebagai berikut :

Total Asset Turnover $=$ Penjualan : Total Aktiva

\section{Rasio Profitabilitas}

Menurut Munawir (2014), rasio profitabilitas adalah ukuran yang menunjukkan kemampuan perusahaan untuk menghasilkan laba pada periode tertentu. Semakin baik rasio profitabilitas maka semakin baik menggambarkan kemampuan tingginya perolehan keuntungan perusahaan. Sedangkan Sartono (2010) menyatakan profitabilitas yaitu kemampuan perusahaan memperoleh laba dalam hubungannya dengan penjualan, total aktiva maupun modal sendiri.

1. Profit Margin on Sales

Profit Margin on Sales merupakan salah satu rasio yang digunakan untuk mengukur margin laba atas penjualan. Cara pengukuran rasio ini adalah dengan membandingkan laba bersih setelah pajak dengan penjulan bersih. Rasio ini juga menilai kemampuan manajemen perusahaan untuk tetap mengontrol berbagai pengeluaran yang langsung digunakan dalam mengahasilkan penjualan. Rumus Profit Margin on Sales yang digunakan adalah sebagai berikut :

Profit Margin on Sales = Penjualan Bersih-Harga Pokok Penjualan : Sales

2. Return On Asset 
Return On assets (ROA) adalah rasio profitabilitas yang mengukur kemampuan perusahaan menghasilkan laba dari penggunaan seluruh sumber daya atau aset yang dimilikinya. Sebagai rasio profitabilitas, ROA digunakan untuk menilai kualitas dan kinerja perusahaan dalam menghasilkan laba bersih dari pemanfaatan aset yang dimilikinya. Secara lebih sederhana, ROA dapat didefinisikan sebagai hasil perbandingan antara laba bersih setelah pajak dengan total aset yang dimiliki suatu perusahaan. Rumus Return On Asset yang digunakan adalah sebagai berikut :

Return On Asset = Laba Setelah Bunga dan Pajak : Total Aktiva

3. Hasil Pengembalian Ekuitas (Return On Equity)

Pengembalian ekuitas atau ROE (Return On Equity) adalah salah satu perhitungan yang masuk dalam rasio profitabilitas. ROE merupakan perhitungan rasio yang menunjukkan kemampuan perusahaan dalam menghasilkan laba bersih dengan menggunakan modal sendiri dan menghasilkan laba bersih yang tersedia bagi pemilik atau investor. Rumus yang digunakan yaitu:

ROE $=$ Laba Setelah Bunga dan Pajak : Total Ekuitas x 100\%

\section{METODE PENELITIAN}

\section{Jenis dan Sumber Data}

1. Jenis Data

a. Data Kualitatif

Menurut Sugiyono (2014), data kualitatif adalah data yang berbentuk kalimat, kata atau gambar. Data kualitatif yang digunakan adalah teori-teori dan deksripsi umum. Yang dimana dalam penelitian ini dilakukan di PT Tempo Scan Pasific Tbk, (TPSC). Data-data ini digunakan untuk pengembangan analisis Rasio Keuangan dalam komparatif laporan keuangan PT Tempo Scan Pasific Tbk, (TPSC).

\section{b. Data Kuantitatif}

Menurut Sugiyono (2014), data kuantitatif adalah data yang berbentuk angka atau data kualitatif yang diangkakan. Yang dimana data kuantitatif yang digunakan dalam penelitian ini adalah laporan keuangan PT Tempo Scan Pasific Tbk, (TPSC) dari tahun 2014-2019. Data-data ini digunakan untuk mengetahui jumlah atau besaran dari analisis Rasio Keuangan dalam komparatif laporan keuangan PT Tempo Scan Pasific Tbk, (TPSC).

\section{Sumber Data}

Sumber data yang digunakan dalam penelitian ini adalah data sekunder. Menurut Sugiarto (2017), data sekunder merupakan informasi yang diperoleh tidak secara langsung dari narasumber melainkan dari pihak ketiga. Menurut Husein Umar (2013) data sekunder adalah merupakan data primer yang telah diolah lebih lanjut dan disajikan baik oleh pihak pengumpul data primer atau oleh pihak lain misalnya dalam bentuk tabel-tabel atau diagram- diagram. Dalam penelitian ini, data sekunder diperoleh melalui internet, buku-buku, jurnal dan tesis yang berhubungan dengan penelitian ini.

\section{Metode Pengumpulan Data}


Adapun metode pengumpulan data yang digunakan yaitu :

1. Menurut Nazir (2013) studi kepustakaan adalah teknik pengumpulan data dengan mengadakan studi penelaahan terhadap buku, literatur dan laporan yang ada hubungannya dengan masalah yang dipecahkan. Studi kepustakaan yaitu mengadakan penelitian dengan cara mempelajari literature yang ada hubungannya dengan permasalahan yang menjadi obyek penelitian.

2. Menurut Sugiyono (2015) dokumen adalah cara yang digunakan untuk memperoleh data dan informasi dalam bentuk buku, dokumen, tulisan angka dan gambar yang berupa laporan serta keterangan yang dapat mendukung penelitian. Dokumen digunakan untuk mengumpulkan data kemudian ditelaah. Data yang digunakan dalam dokumen ini berupa PT Tempo Scan Pasific Tbk. (TPSC). Yang diperoleh melalui situs https://www.temposcangroup.com/ dan data laporan keuangan perusahaan dari tahun 2014-2019 yang diperoleh dari Bursa Efek Indonesia (BEI) yang diunduh melalui situs http://www.idx.co.id.

\section{HASIL DAN PEMBAHASAN Metode Analisis Data}

Metode analisis data yang digunakan dalam penelitian ini adalah analisis statistik deskriptif. Statistik deskriptif adalah statistik yang digunakan untuk menganalisis data dengan cara mendeskripsian atau menggambarkan data yang terkumpul sebagaimana adanya tanpa bermaksud membuat kesimpulan yang berlaku untuk umum atau generalisasi. Dengan kata statistika deskriptif berfungsi menerangkan keadaan, gejala, atau persoalan (Sugiyono, 2015).

Tabel 2 Analsis Rasio Keuangan

\begin{tabular}{|c|c|c|c|c|c|c|c|c|c|c|c|c|}
\hline \multirow{2}{*}{ KETERANGAN } & \multicolumn{2}{|c|}{2014} & \multicolumn{2}{|c|}{2015} & \multicolumn{2}{|c|}{2016} & \multicolumn{2}{|c|}{2017} & \multicolumn{2}{|c|}{2018} & \multicolumn{2}{|c|}{2019} \\
\hline & TPSC & Industri & TPSC & Industri & TPSC & Industri & TPSC & Industri & TPSC & Industri & TPSC & Industri \\
\hline \multicolumn{13}{|c|}{ RASIOLIKUIDITAS } \\
\hline Current Ratio & 1,54 & 0,81 & 1,39 & 0,95 & 1,64 & 1,03 & 1,20 & 1,22 & 1,39 & 1,13 & 2,00 & 1,23 \\
\hline Quick Ratio & 0,95 & 0,54 & 0,89 & 0,68 & 1,15 & 0,78 & 0,76 & 0,91 & 0,97 & 0,89 & 1,55 & 0,98 \\
\hline \multicolumn{13}{|c|}{ RASIOSOLVABILITAS } \\
\hline Total Debt Ratio & 0,41 & 0,62 & 0,50 & 0,55 & 0,50 & 0,56 & 0,50 & 0,50 & 0,45 & 0,49 & 0,31 & 0,41 \\
\hline Debt Equity Ratio & 0,71 & 1,66 & 0,99 & 1,22 & 1,00 & 1,27 & 0,99 & 0,98 & 0,83 & 0,94 & 0,45 & 0,71 \\
\hline Capital Structure & 0,18 & 0,29 & 0,38 & 0,29 & 0,49 & 0,39 & 0,41 & 0,32 & 0,28 & 0,18 & 0,14 & 0,15 \\
\hline \multicolumn{13}{|c|}{ RASIO TURNOVER ASSET } \\
\hline Inventory Turnover & 3,03 & 5,13 & 3,33 & 6,57 & 4,48 & 7,06 & 3,48 & 6,40 & 3,80 & 6,71 & 5,30 & 7,85 \\
\hline Receivable Turnover & 5,48 & 7,47 & 5,28 & 9,06 & 5,76 & 8,32 & 5,72 & 7,00 & 6,00 & 6,06 & 6,11 & 5,04 \\
\hline Days' Sales in Receivables & 66,62 & 48,87 & 69,19 & 40,27 & 63,35 & 43,86 & 63,83 & 52,11 & 60,86 & 60,19 & 59,78 & 72,37 \\
\hline Total Asset Turnover & 1,15 & 1,29 & 1,03 & 1,26 & 1,16 & 1,26 & 0,97 & 1,23 & 0,91 & 1,13 & 1,01 & 1,22 \\
\hline \multicolumn{13}{|c|}{ RASIOPROFITABILITAS } \\
\hline Profit Margin & $5,37 \%$ & $16,55 \%$ & $4,90 \%$ & $12,11 \%$ & $6,30 \%$ & $17,88 \%$ & $4,70 \%$ & $22,42 \%$ & $6,58 \%$ & $21,27 \%$ & $10,05 \%$ & $22,00 \%$ \\
\hline Return On Asset & $6,15 \%$ & $21,41 \%$ & $5,03 \%$ & $15,31 \%$ & $7,29 \%$ & $22,53 \%$ & $4,55 \%$ & $27,69 \%$ & $6,01 \%$ & $23,94 \%$ & $10,20 \%$ & $26,86 \%$ \\
\hline Return On Equity & $10,50 \%$ & $57,03 \%$ & $10,00 \%$ & $34,01 \%$ & $14,56 \%$ & $51,07 \%$ & $9,04 \%$ & $54,87 \%$ & $10,99 \%$ & $46,51 \%$ & $14,77 \%$ & $45,91 \%$ \\
\hline
\end{tabular}

Sumber: Laporan Keuangan Tahunan PT Tempo Scan Pasific Tbk. (https://www.idx.co.id 


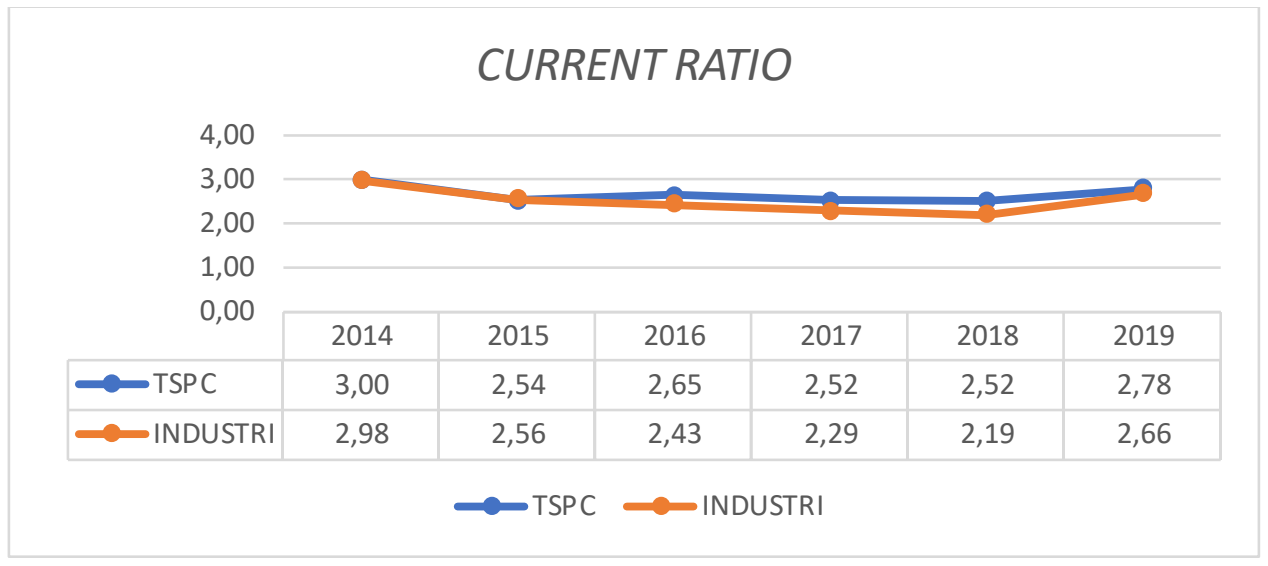

\section{Grafik 1. Perbandingan Current Ratio TPSC dan industrinya}

Dalam current ratio, apabila memiliki nilai $>1$ yang menunjukkan bahwa perusahaan dianggap mampu memenuhi segala kewajiban jangka pendeknya. Apabila nilai current ratio $<1$ maka, perusahaan dianggap tidak mampu memenuhi segala kewajiban jangka pendeknya.

Berdasarkan grafik diatas dapat dilihat bahwa perbandingan current ratio PT Tempo Scan Pasific Tbk, (TPSC) dengan total industri pharmaceutical bervariasi dari tahun ke tahun. Oleh karena itu untuk hasil yang lebih akurat akan dilakukan rata-rata nilai current ratio selama enam tahun. Hasil rata-rata nilai current ratio PT Tempo Scan Pasific Tbk, (TPSC) sebesar 2,67 sedangkan total industri pharmaceutical sebesar 2,52. Sehingga dapat disimpulkan bahwa nilai current ratio PT Tempo Scan Pasific Tbk, (TPSC) berada pada posisi lebih tinggi di bandingkan dengan total industri pharmaceutical. Dapat disimpulkan bahwa PT Tempo Scan Pasific Tbk, (TPSC) lebih baik di bandingkan total ind ustri pharmaceutical.

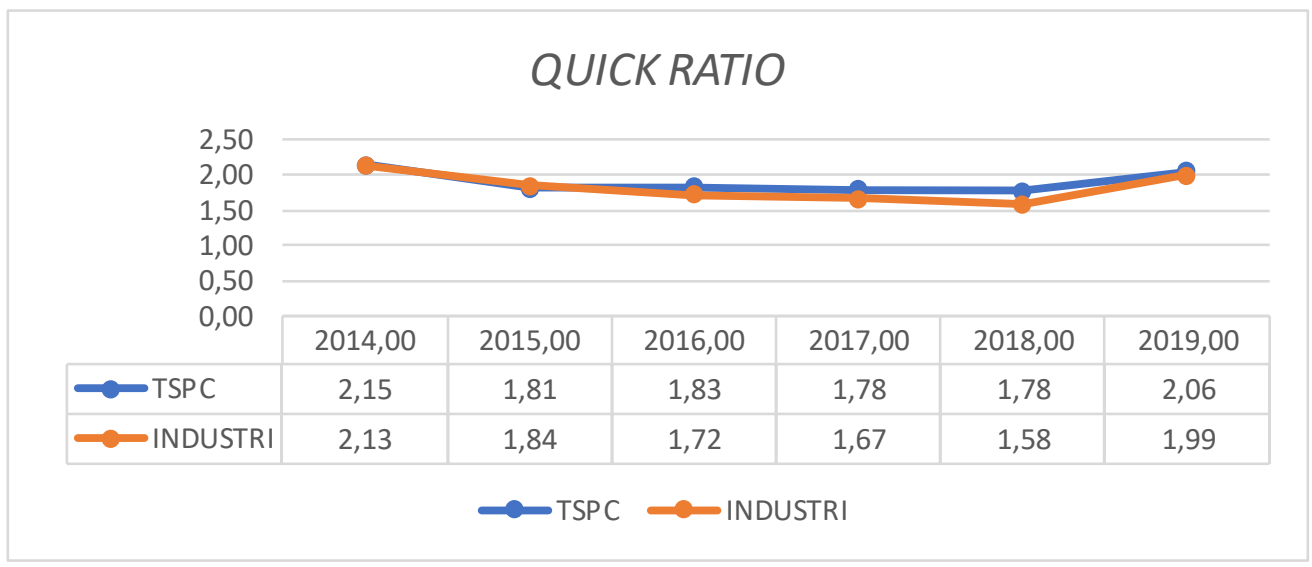

Grafik 2. Perbandingan Quick Ratio TPSC dan Industrinya

Dalam quick ratio yang memiliki nilai $>1$ yang menunjukkan bahwa perusahaan dianggap mampu memenuhi segala kewajiban jangka pendeknya. Apabila nilai quick ratio $<1$, maka perusahaan dianggap tidak mampu memenuhi segala kewajiban jangka pendeknya. 
Berdasarkan grafik diatas dapat dilihat bahwa perbandingan quick ratio PT Tempo Scan Pasific Tbk, (TPSC) dengan total industri pharmaceutical bervariasi dari tahun ke tahun. Oleh karena itu, untuk hasil yang lebih akurat akan dilakukan rata-rata nilai quick ratio selama enam tahun. Hasil rata-rata nilai current ratio PT Tempo Scan Pasific Tbk, (TPSC) sebesar 1,90 sedangkan total industri pharmaceutical sebesar 1,82. Sehingga dapat disimpulkan bahwa nilai current ratio PT Tempo Scan Pasific Tbk, (TPSC) berada pada posisi lebih tinggi di bandingkan dengan total industri pharmaceutical. Dapat disimpulkan bahwa PT Tempo Scan Pasific Tbk, (TPSC) lebih baik di bandingkan total industri pharmaceutical.

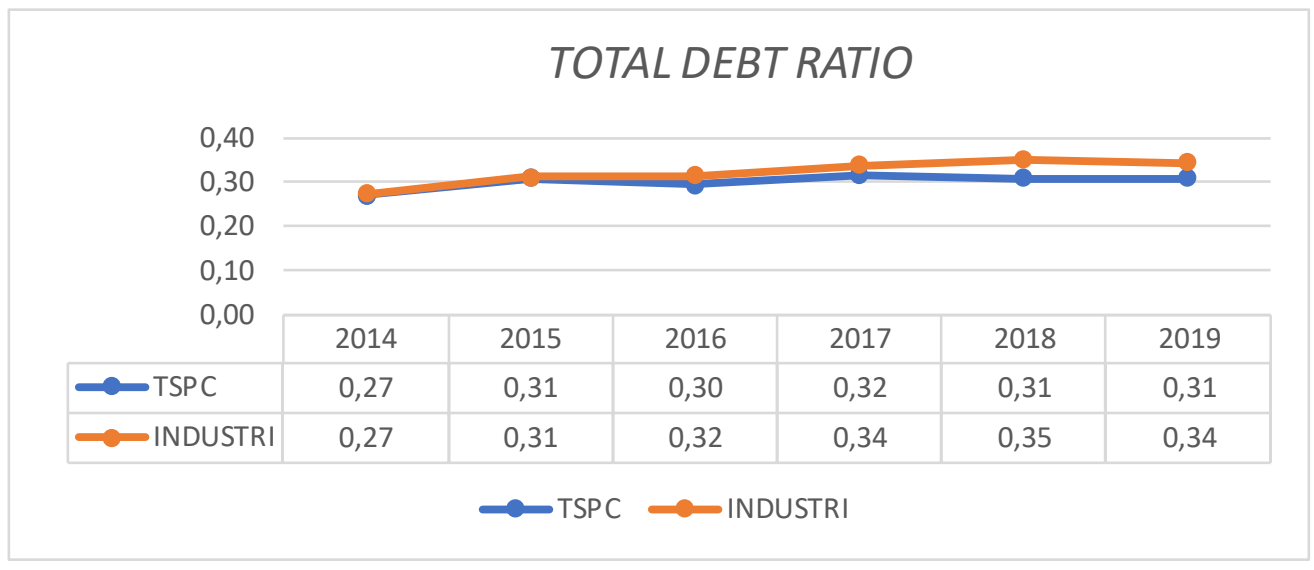

\section{Grafik 3. Perbandingan Total Debt Ratio TPSC dan Industrinya}

Total debt ratio dapat menunjukkan seberapa besar aktiva yang dimiliki oleh perusahaan dibiayai oleh hutang. Semakin besar nilai rasio ini artinya aktiva yang dimiliki oleh perusahaan dibiayai atau dibeli dengan menggunakan hutang. Sehingga semakin besar nilai rasio ini maka semakin besar pula risiko bagi para kreditur atau pihak yang memberikan pinjaman kepada perusahaan.

Berdasarkan grafik diatas dapat dilihat bahwa perbandingan total debt ratio PT Tempo Scan Pasific Tbk, (TPSC) perbandingan dengan total industri pharmaceutical bervariasi dari tahun ke tahun. Oleh karena itu untuk hasil yang lebih akurat akan dilakukan rata-rata nilai Total debt ratio selama enam tahun. Hasil rata-rata nilai Total debt ratio PT Tempo Scan Pasific Tbk, (TPSC) sebesar 0,30 sedangkan total industri pharmaceutical sebesar 0,32. Sehingga dapat disimpulkan bahwa nilai total debt ratio PT Tempo Scan Pasific Tbk, (TPSC) berada pada posisi lebih rendah di bandingkan dengan total industri pharmaceutical. Dapat disimpulkan bahwa PT Tempo Scan Pasific Tbk, (TPSC) lebih baik di bandingkan total industri pharmaceutical. 


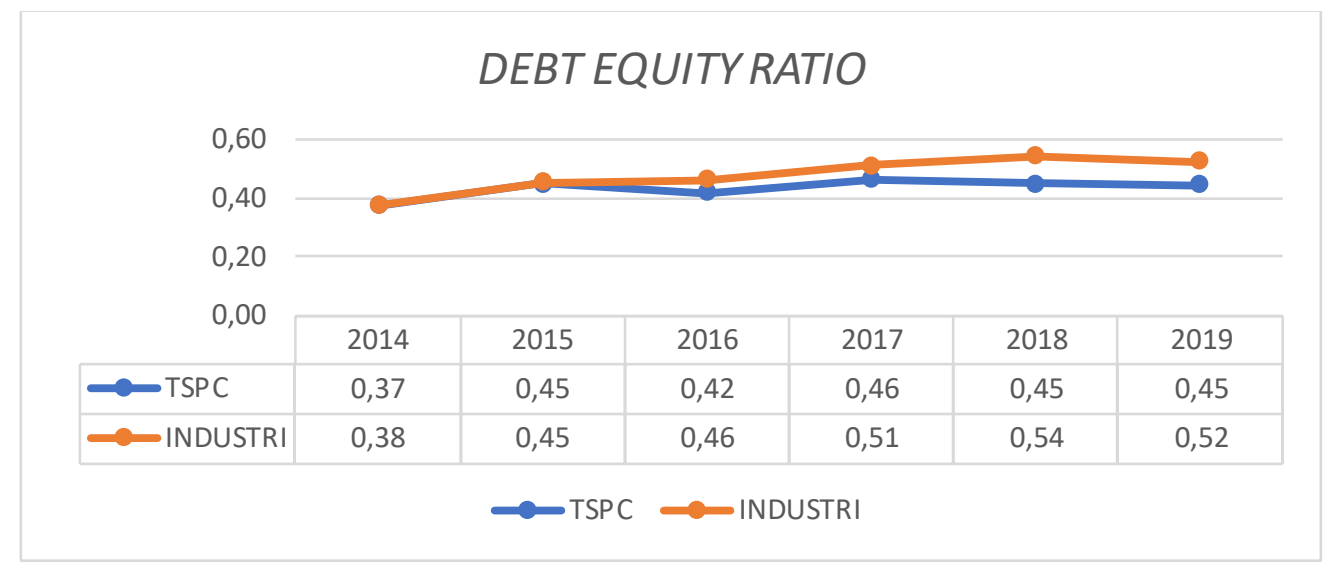

\section{Grafik 4. Perbandingan Debt Equity Ratio TPSC dan Industrinya}

Debt equity ratio dapat menunjukkan seberapa besar ekuitas atau modal yang dimiliki oleh perusahaan dibiayai oleh hutang. Semakin besar nilai rasio ini artinya aktiva yang dimiliki oleh perusahaan dibiayai atau dibeli dengan menggunakan hutang. Sehingga semakin besar nilai rasio ini maka semakin besar pula risiko bagi pihak yang memberikan pinjaman kepada perusahaan.

Berdasarkan grafik diatas dapat dilihat bahwa perbandingan debt equity ratio PT Tempo Scan Pasific Tbk, (TPSC) perbandingan dengan total industri pharmaceutical bervariasi dari tahun ke tahun. Oleh karena itu untuk hasil yang lebih akurat akan dilakukan rata-rata nilai debt equity ratio selama enam tahun. Hasil rata-rata nilai debt equity ratio PT Tempo Scan Pasific Tbk, (TPSC) sebesar 0,43 sedangkan total industri pharmaceutical sebesar 0,48. Sehingga dapat disimpulkan bahwa nilai debt equity ratio PT Tempo Scan Pasific Tbk, (TPSC) berada pada posisi lebih rendah di bandingkan dengan total industri pharmaceutical. Dapat disimpulkan bahwa PT Tempo Scan Pasific Tbk, (TPSC) lebih baik di bandingkan total industri pharmaceutical.

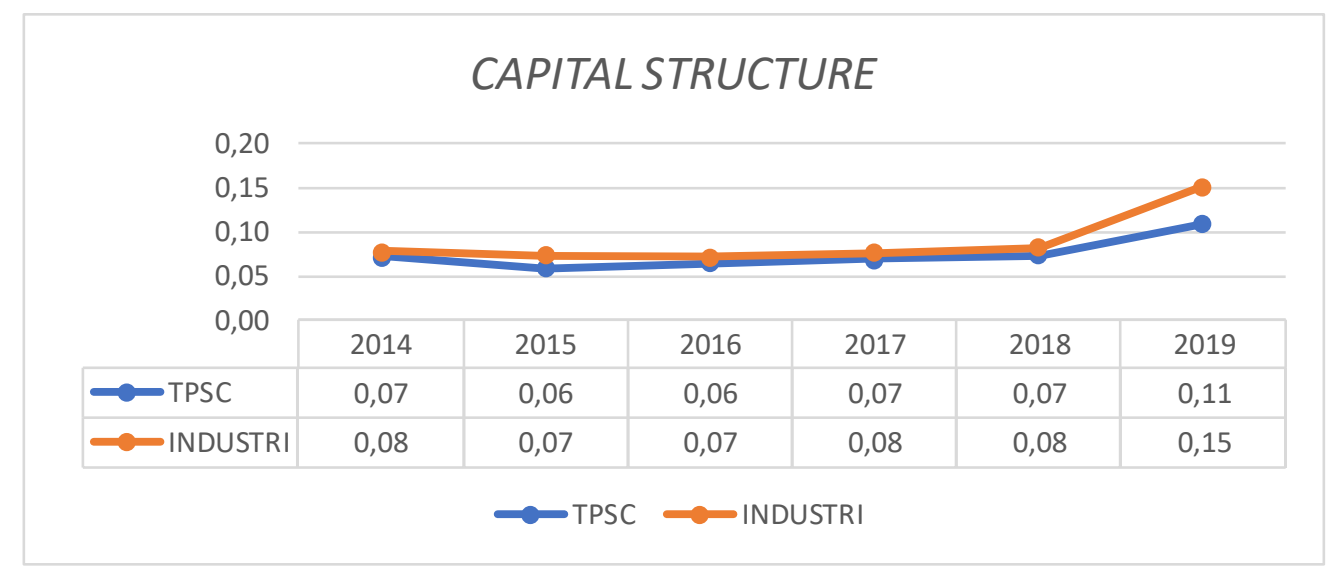

Grafik 5. Perbandingan Capital Structure TPSC dan Industrinya 
Capital Structure dapat menunjukkan seberapa besar aset atau modal yang dimiliki perusahaan dibiayai atau berasal dari hutang jangka Panjang. Semakin besar nilai rasio ini artinya modal yang dimiliki perusahaan sebagian besar berasal dari pinjaman atau hutang jangka panjang.

Berdasarkan grafik diatas dapat melihat bahwa capital structure PT Tempo Scan Pasific Tbk, (TPSC) perbandingan dengan total industri pharmaceutical bervariasi dari tahun ke tahun. Oleh karena itu untuk hasil yang lebih akurat akan dilakukan rata-rata nilai capital structure selama enam tahun. Hasil rata-rata nilai capital structure PT Tempo Scan Pasific Tbk, (TPSC) sebesar 0,07 sedangkan total industri pharmaceutical sebesar 0,09. Sehingga dapat disimpulkan bahwa nilai capital structure PT Tempo Scan Pasific Tbk, (TPSC) berada pada posisi lebih rendah di bandingkan dengan total industri pharmaceutical. Dapat disimpulkan bahwa PT Tempo Scan Pasific Tbk, (TPSC) lebih baik di bandingkan total industri pharmaceutical.

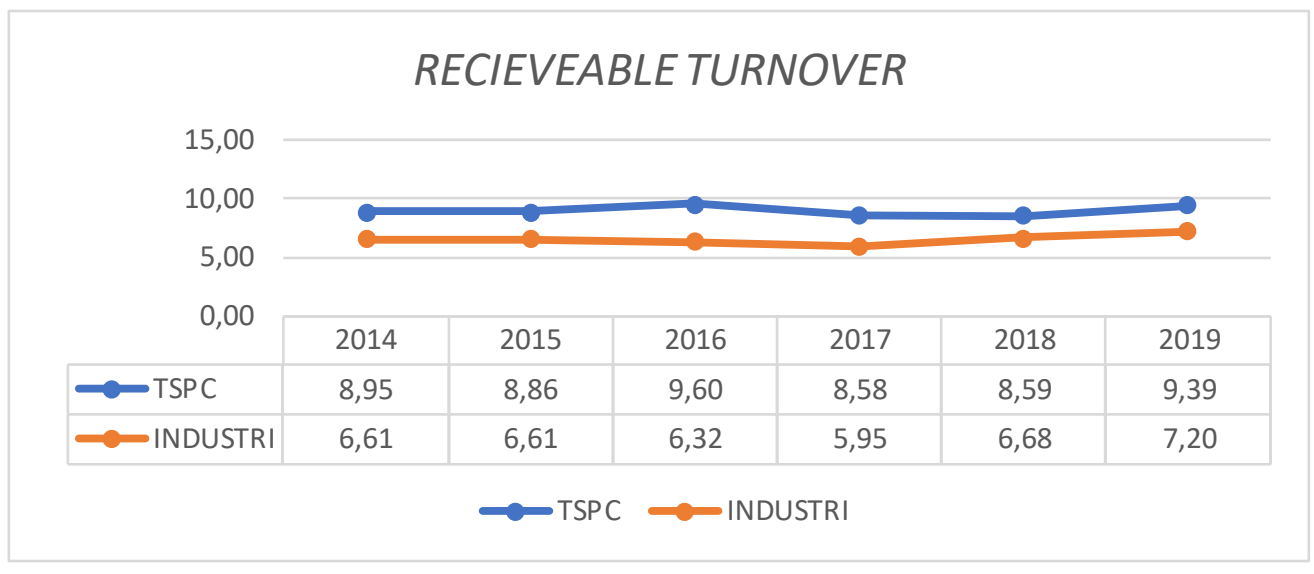

\section{Grafik 6. Perbandingan Receivable Turnover TPSC dan Industrinya}

Receivable turnover dapat menunjukkan berapa kali piutang dapat berputar dalam setahun. Semakin tinggi nilai receivable turnover pada perusahaan maka piutang yang dapat ditagih oleh perusahaan semakin tinggi oleh perusahaan sehingga memperkecil kemungkinan piutang tidak tertagih dan baik juga bagi arus kas perusahaan.

Berdasarkan grafik diatas dapat melihat bahwa receivable turnover PT Tempo Scan Pasific Tbk, (TPSC) perbandingan dengan total industri pharmaceutical bervariasi dari tahun ke tahun. Oleh karena itu untuk hasil yang lebih akurat akan dilakukan rata-rata nilai receivable turnover selama enam tahun. Hasil rata-rata nilai receivable turnover PT Tempo Scan Pasific Tbk, (TPSC) sebesar 9,00 sedangkan total industri pharmaceutical sebesar 6,56. Sehingga dapat disimpulkan bahwa nilai receivable turnover PT Tempo Scan Pasific Tbk, (TPSC) berada pada posisi lebih tinggi di bandingkan dengan total industri pharmaceutical. Dapat disimpulkan bahwa PT Tempo Scan Pasific Tbk, (TPSC) lebih baik di bandingkan total industri pharmaceutical. 


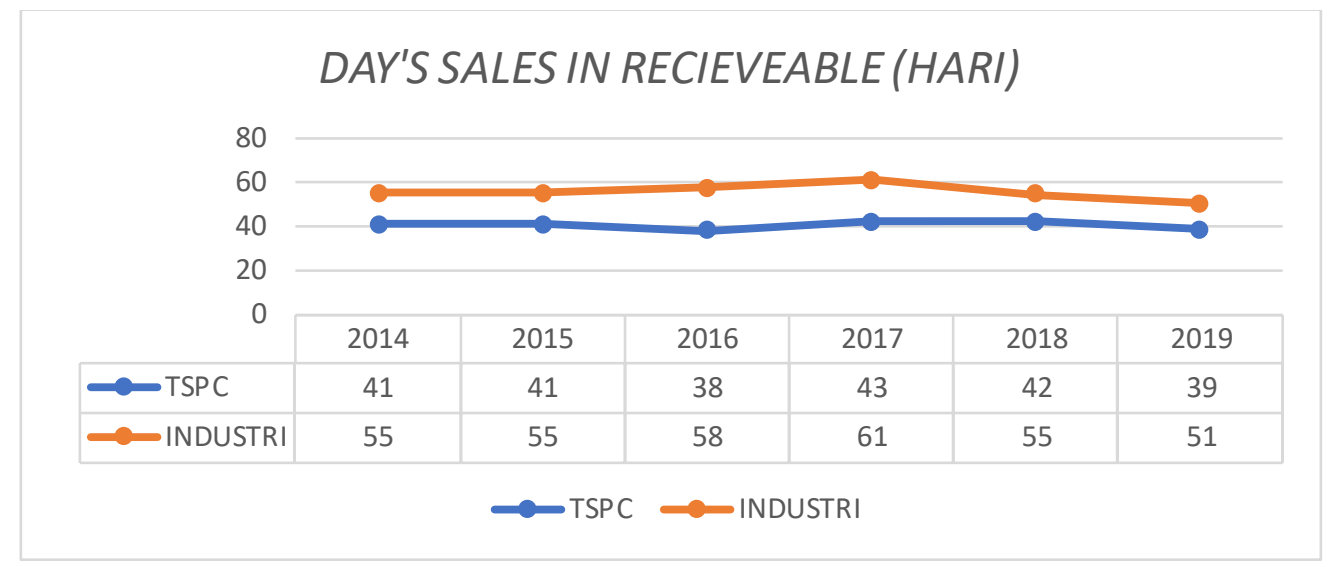

\section{Grafik 7. Perbandingan Day's Sale In Receivable TPSC dan Industrinya}

Day's sale in receivable dapat menunjukkan berapa lama rata-rata waktu yang dibutuhkan perusahaan untuk menagih setiap piutang yang tertagih. Semakin kecil nilai day's sale in receivable semakin cepat piutang dilunasi.

Berdasarkan grafik diatas dapat melihat bahwa day's sale in receivable PT Tempo Scan Pasific Tbk, (TPSC) perbandingan dengan total industri pharmaceutical bervariasi dari tahun ke tahun. Oleh karena itu untuk hasil yang lebih akurat akan dilakukan rata-rata nilai day's sale in receivable selama enam tahun. Hasil rata-rata nilai day's sale in receivable PT Tempo Scan Pasific Tbk, (TPSC) sebesar 41 hari sedangkan total industri pharmaceutical sebesar 56 hari. Sehingga dapat disimpulkan bahwa nilai day's sale in receivable PT Tempo Scan Pasific Tbk, (TPSC) berada pada posisi lebih rendah di bandingkan dengan total industri pharmaceutical. Dapat disimpulkan bahwa PT Tempo Scan Pasific Tbk, (TPSC) lebih baik di bandingkan total ind ustri pharmaceutical.

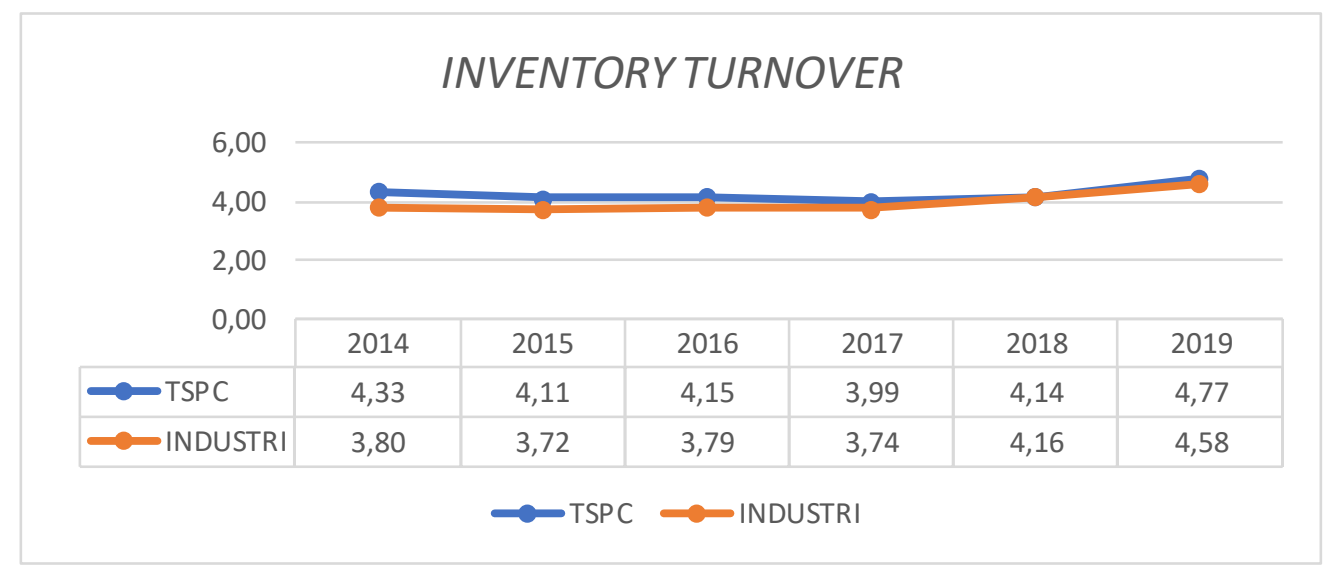

Grafik 8. Perbandingan Inventory Turnover TPSC dan Industrinya

Inventory turnover dapat menunjukkan berapa kali persediaan dapat berputar dalam satu tahun atau dapat juga dikatakan rasio ini menunjukkan tingkat efisiensi dan efektifitas dari persediaan. Semakin tinggi nilai inventory turnover menunjukkan perusahaan menjual persediaan secara maksimal. 
Berdasarkan grafik diatas dapat melihat bahwa inventory turnover PT Tempo Scan Pasific Tbk, (TPSC) perbandingan dengan total industri pharmaceutical bervariasi dari tahun ke tahun. Oleh karena itu untuk hasil yang lebih akurat akan dilakukan rata-rata nilai inventory turnover selama enam tahun. Hasil rata-rata nilai inventory turnover PT Tempo Scan Pasific Tbk, (TPSC) sebesar 4,25 sedangkan total industri pharmaceutical sebesar 3,97. Sehingga dapat disimpulkan bahwa nilai inventory turnover PT Tempo Scan Pasific Tbk, (TPSC) berada pada posisi lebih tinggi di bandingkan dengan total industri pharmaceutical. Dapat disimpulkan bahwa PT Tempo Scan Pasific Tbk, (TPSC) lebih baik di bandingkan total industri pharmaceutical.

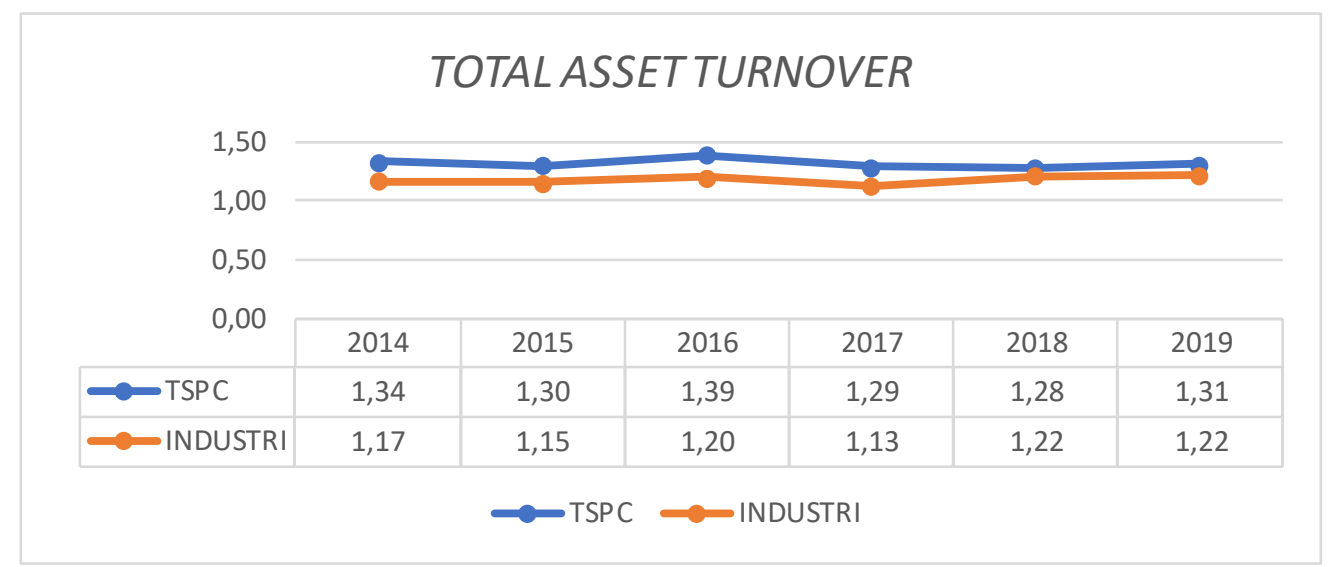

\section{Grafik 9. Perbandingan Total Asset Turnover TPSC dan Industrinya}

Total asset turnover dapat menunjukkan kemampuan perusahaan dalam mengelola seluruh asset yang dimilikinya untuk menghasilkan penjualan. Semakin tinggi total asset turnover semakin tinggi pula penjualan yang dilakukan oleh perusahaan dari hasil mengelola asset yang dimilikinya.

Berdasarkan grafik diatas dapat melihat bahwa total asset turnover PT Tempo Scan Pasific Tbk, (TPSC) perbandingan dengan total ind ustri pharmaceutical bervariasi dari tahun ke tahun. Oleh karena itu untuk hasil yang lebih akurat akan dilakukan rata-rata nilai total asset turnover selama enam tahun. Hasil rata-rata nilai total asset turnover PT Tempo Scan Pasific Tbk, (TPSC) sebesar 1,32 sedangkan total industri pharmaceutical sebesar 1,18. Sehingga dapat disimpulkan bahwa nilai total asset turnover PT Tempo Scan Pasific Tbk, (TPSC) berada pada posisi lebih tinggi di bandingkan dengan total industri pharmaceutical. Dapat disimpulkan bahwa PT Tempo Scan Pasific Tbk, (TPSC) lebih baik di bandingkan total industri pharmaceutical. 


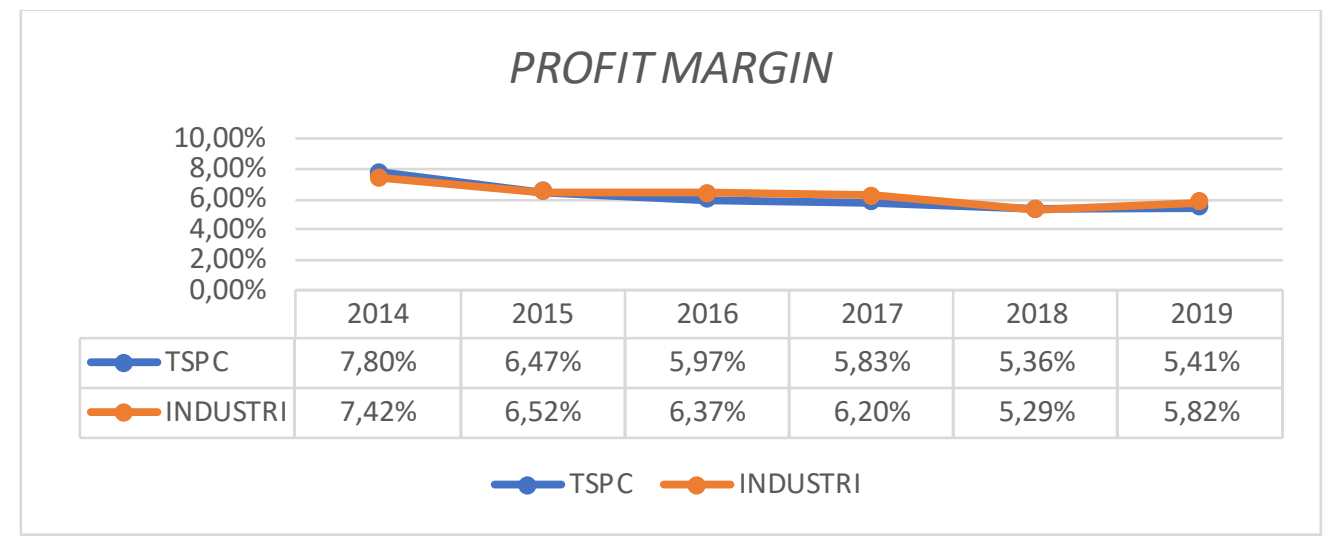

Grafik 10. Perbandingan Profit Margin TPSC dan Industrinya

Profit margin dapat menunjukkan kemampuan seberapa besar keuntungan yang dapat diperoleh perusahaan dari aktivitas penjualan. Semakin tinggi nilai profit margin maka semakin tinggi pula laba yang dihasilkan perusahaan dari aktivitas penjualan.

Berdasarkan grafik diatas dapat melihat bahwa profit margin PT Tempo Scan Pasific Tbk, (TPSC) perbandingan dengan total industri pharmaceutical bervariasi dari tahun ke tahun. Oleh karena itu untuk hasil yang lebih akurat akan dilakukan rata-rata nilai profit margin selama enam tahun. Hasil rata-rata nilai profit margin PT Tempo Scan Pasific Tbk, (TPSC) sebesar 6,14\% sedangkan total industri pharmaceutical sebesar 6,27\%. Sehingga dapat disimpulkan bahwa nilai profit margin PT Tempo Scan Pasific Tbk, (TPSC) berada pada posisi lebih rendah di bandingkan dengan total industri pharmaceutical. Dapat disimpulkan bahwa total industri pharmaceutical lebih baik di bandingkan PT Tempo Scan Pasific Tbk, (TPSC).

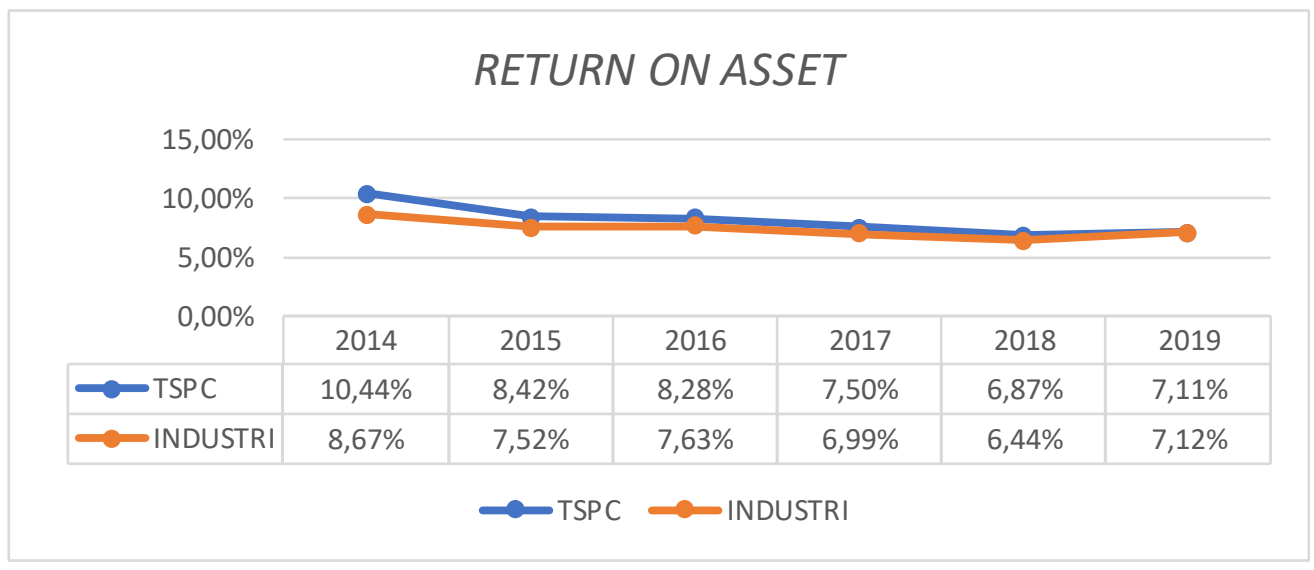

\section{Grafik 11. Perbandingan Return On Asset TPSC dan Industrinya}

Return on asset dapat menunjukkan seberapa besar keuntungan yang dapat diperoleh atau dihasilkan perusahaan dari asset yang dimiliki perusahaan. Semakin tinggi nilai return on asset maka semakin tinggi pula laba yang dihasilkan perusahaan dari asset yang dimilikinya.

Berdasarkan grafik diatas dapat melihat bahwa return on asset PT Tempo Scan Pasific Tbk, (TPSC) perbandingan dengan total industri pharmaceutical bervariasi dari tahun ke tahun. 
Oleh karena itu untuk hasil yang lebih akurat akan dilakukan rata-rata nilai return on asset selama enam tahun. Hasil rata-rata nilai return on asset PT Tempo Scan Pasific Tbk, (TPSC) sebesar 8,10\% sedangkan total industri pharmaceutical sebesar 7,40\%. Sehingga dapat disimpulkan bahwa nilai return on asset PT Tempo Scan Pasific Tbk, (TPSC) berada pada posisi lebih tinggi di bandingkan dengan total industri pharmaceutical. Dapat disimpulkan bahwa PT Tempo Scan Pasific Tbk, (TPSC) lebih baik di bandingkan total industri pharmaceutical.

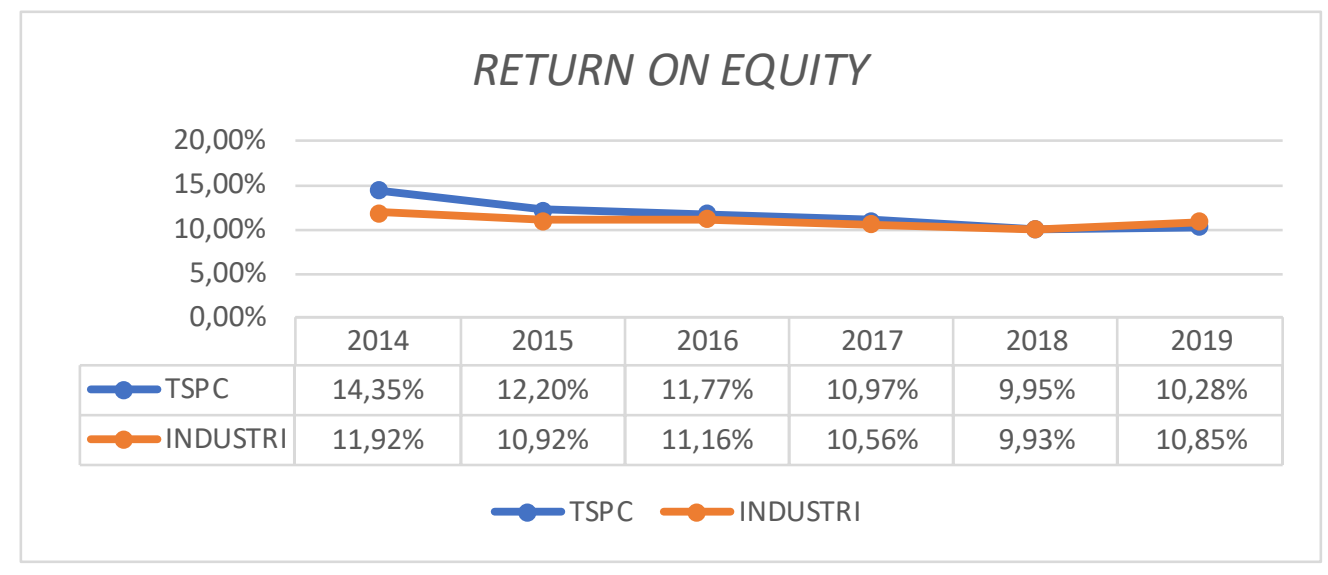

\section{Grafik 12 Perbandingan Return On Equity TPSC dan Industrinya}

Return on equity dapat menunjukkan seberapa besar keuntungan yang dapat diperoleh atau dihasilkan perusahaan dari ekuitas atau modal yang dimiliki perusahaan. Semakin tinggi nilai return on equity maka semakin tinggi pula laba yang dihasilkan perusahaan dari ekuitas atau modal yang dimilikinya.

Berdasarkan grafik diatas dapat melihat bahwa return on equity PT Tempo Scan Pasific Tbk, (TPSC) perbandingan dengan total industri pharmaceutical bervariasi dari tahun ke tahun. Oleh karena itu untuk hasil yang lebih akurat akan dilakukan rata-rata nilai return on equity selama enam tahun. Hasil rata-rata nilai return on equity PT Tempo Scan Pasific Tbk, (TPSC) sebesar 11,59\% sedangkan total industri pharmaceutical sebesar 10,89\%. Sehingga dapat disimpulkan bahwa nilai return on equity PT Tempo Scan Pasific Tbk, (TPSC) berada pada posisi lebih tinggi di bandingkan dengan total industri pharmaceutical. Dapat disimpulkan bahwa PT Tempo Scan Pasific Tbk, (TPSC) lebih baik di bandingkan total industri pharmaceutical.

\section{KESIMPULAN}

Berdasarkan analisis komparatif laporan keuangan PT Tempo Scan Pasific Tbk, (TPSC) dengan ind ustri pharmaceutical yang terd aftar di Bursa Efek Indonesia (BEI) pada periode 20142019 dapat diperoleh kesimpulan sebagai berikut :

- Current Ratio dapat disimpulkan bahwa PT Tempo Scan Pasific Tbk, (TPSC) lebih baik di bandingkan total industri pharmaceutical.

- Quick Ratio dapat disimpulkan bahwa PT Tempo Scan Pasific Tbk, (TPSC) lebih baik di bandingkan total industri pharmaceutical. 
- Total Debt Ratio dapat disimpulkan bahwa PT Tempo Scan Pasific Tbk, (TPSC) lebih baik di bandingkan total industri pharmaceutical.

- Debt Equity Ratio dapat disimpulkan bahwa PT Tempo Scan Pasific Tbk, (TPSC) lebih baik di bandingkan total industri pharmaceutical.

- Capital Structure dapat disimpulkan bahwa PT Tempo Scan Pasific Tbk, (TPSC) lebih baik di bandingkan total industri pharmaceutical.

- Receivable Turnover dapat disimpulkan bahwa PT Tempo Scan Pasific Tbk, (TPSC) lebih baik di bandingkan total industri pharmaceutical.

- Day's Sale in Receivable dapat disimpulkan bahwa PT Tempo Scan Pasific Tbk, (TPSC) lebih baik di bandingkan total industri pharmaceutical.

- Inventory Turnover dapat disimpulkan bahwa PT Tempo Scan Pasific Tbk, (TPSC) lebih baik di bandingkan total industri pharmaceutical.

- Total Asset Turnover dapat disimpulkan bahwa PT Tempo Scan Pasific Tbk, (TPSC) lebih baik di bandingkan total industri pharmaceutical.

- Profit Margin dapat disimpulkan bahwa total industri pharmaceutical lebih baik di bandingkan PT Tempo Scan Pasific Tbk, (TPSC).

- Return on Asset dapat disimpulkan bahwa PT Tempo Scan Pasific Tbk, (TPSC) lebih baik di bandingkan total industri pharmaceutical.

- Return on Equity dapat disimpulkan bahwa PT Tempo Scan Pasific Tbk, (TPSC) lebih baik di bandingkan total industri pharmaceutical.

Berdasarkan 12 analisis rasio laporan keuangan yang telah di teliti, maka dapat ditarik kesimpulan secara keseluruhan adalah bahwa PT Tempo Scan Pasific Tbk, (TPSC) lebih baik mengungguli industri pharmaceutical. Akan tetapi tidak lebih baik mengungguli dalam analisa profit margin. Profit margin merupakan rasio yang digunakan untuk mengukur besarnya persentase laba kotor atas penjualan bersih (Kasmir, 2014).

\section{REFERENSI}

Agus Harjito dan Martono. 2010. Manajemen Keuangan. Yogyakarta: Ekonisia.

Brigham, Eugene F. Dan J.F. Houston. 2010. Dasar-Dasar Manajemen Keuangan. Edisi 11. Jakarta: Salemba Empat.

Fahmi, Irham. 2011. Analisis Kinerja Keuangan. Bandung: Alfabeta.

Fahmi, Irham. 2012. Manjemen Investasi Teori dan Soal Jawab. Jakarta: Salemba Empat.

Hans Kartikahadi., dkk. 2016. Akuntansi Keuangan Berdasarkan SAK Berbasis IFRS. Buku 1. Jakarta : Salemba Empat.

Harahap, Sofyan Syafri, 2013. Analisis Kritis Atas Laporan Keuangan, Cetakan Kesebelas, Jakarta : Rajawali Pers.

Hery. 2015. Analisis Laporan Keuangan. Cetakan pertama. Yogyakarta: CAPS.

Husein Umar. 2013. Metode Penelitian untuk Skripsi dan Tesis. Jakarta: Rajawali.

Irawati, S. 2006. Manajemen Keuangan, Cetakan Kesatu, Bandung : Pustaka. 
Kasmir, 2014. Analisis Laporan Keuangan, cetakan ke-7. Jakarta: PT RajaGrafindo Persada.

Kasmir. 2016. Analisis Laporan Keuangan. Jakarta : PT. RajaGrafindo Persada.

Munawir, S. 2014. Analisis Laporan Keuangan. Yogyakarta: Liberty.

Nazir, M. 2013. Metode Penelitian. Bogor: Ghalia Indonesia.

Priyati, N. 2013. Pengantar Akuntansi.Jakarta: PT Indeks

Sugiarto, M. 2017. Metodologi Penelitian Bisnis. Yogyakarta: Penerbit ANDI.

Sugiyono. 2015. Metode Penelitian Kuantitatif, Kualitatif, dan R\&D. Bandung: Alfabeta.

Sutrisno. 2012. Manajemen Keuangan Teori Konsep dan Aplikasi. Yogyakarta : Ekonisia. 